\title{
EFEKTIVITAS MODEL PEMBELAJARAN KOLB DALAM MENINGKATKAN HASIL BELAJAR SISWA IPS KELAS XI MA MU'ALLIMIN NW PANCOR
}

\author{
Muhamad Zaril Gapari \\ STIT Palapa Nusantara \\ zagap205@yahoo.co.id
}

\begin{abstract}
Learning economics is not enough to memorize the material alone, but also need to learn to solve problems on your own in everyday life. This can be achieved if the Kolb model learning is applied in classroom learning activities because Kolb learning can stimulate students' thinking higher in problem-oriented situations. Kolb learning provides opportunities for students to be able to develop observations in solving problems in everyday life. This technique can provoke an independent personality. From this fact, researchers are interested in conducting studies on the application of Kolb's learning model to the ability to solve economic problems of class XI MA students. NW Pancor. This study aims to determine the effectiveness of using the Kolb learning model on learning outcomes (IPS) Economics of class XI students on the accounting information system material of MA. Mu'allimin NW Pancor. The method used in this research is the experimental method. The research design used is by using a Quasi experimental design. The population in this study were all students of class XI MA. Mu'allimin NW Pancor, which consists of 2 classes, namely class XI. IPS.I and XI. IPS. 2. Class XI. IPS.I as the control class and XI. IPS.2 as an experimental class. While the data analysis technique uses the $T$ test. After the data analysis was carried out, the price of tcount $=13.18$ and ttable $=2.0042$ at the 5\% significance level with dk $=56$. Because tcount $>$ ttable $(13.18>2.0042)$ then $H 0$ was rejected and Ha was accepted, which means that learning using the Kolb model is more effective than conventional learning models. Based on the results of testing the bypothesis above, it can be concluded that the use of the Kolb model is effective in improving student learning outcomes in class XI. in MA. Mu'allimin NW Pancor.
\end{abstract}

Keywords: Effectiveness, Kolb Model, Learning Outcomes

\begin{abstract}
Abstrak : Belajar ekonomi tidak cukup dengan menghafal materinya saja tetapi juga perlu belajar mengatasi masalah sendiri dalam kehidupan sehari-hari. Hal ini dapat tercapai jika pembelajaran model Kolb di terapkan dalam kegiatan pembelajaran di kelas karena pembelajaran Kolb dapat merangsang berfikir siswa lebih tinggi dalam situasi berorientasi masalah. Pembelajaran kolb memberikan kesempatan untuk siswa untuk dapat mengembangkan observasi dalam menyelesaikan masalah-masalah dalam kehidupan sehari-hari. Teknik ini dapat memancing sifat keperibadian yang mandiri. Dari kenyataan tersebut peneliti tertarik melakukan kajian tentang penerapan model pembelajaran Kolb terhadap kemampuan memecahkan masalah ekonomi siswa kelas XI MA. NW Pancor. Penelitian ini bertujuan untuk mengetahui efektivitas penggunaan model pembelajaran kolb terhadap hasil belajar (IPS) Ekonomi siswa kelas XI pada materi sistem imformasi akuntansi MA. Mu'allimin NW Pancor.
\end{abstract}

Islamika : Jurnal Keislaman dan Ilmu Pendidikan

Volume 3, Nomor 1, Januari 2021; 108-122

https://ejournal.stitpn.ac.id/index.php/islamika 
Metode yang digunakan dalam penelitian ini adalah metode eksperimen. Desain penelitian yang digunakan yaitu dengan menggunakan Quasi experimental design. Populasi dalam penelitian ini adalah seluruh siswa kelas XI MA. Mu'allimin NW Pancor yang berjumlah 2 kelas yakni kelas XI. IPS.I dan XI. IPS.2. Kelas XI. IPS.I sebagai kelaskontrol dan XI. IPS.2 sebagai kelas eksperimen. Sedangkan teknik analisis data yang menggunakan uji T. Setelah analisa data dilakukan, diperoleh harga thitung $=13,18$ dan ttabel $=2,0042$ pada taraf signifikansi $5 \%$ dengan $\mathrm{dk}=56$. Karena thitung $>$ ttabel $(13,18>2,0042)$ maka H0 ditolak dan Ha diterima yang berarti bahwa pembelajaran dengan menggunakan model Kolb lebih efektif dibandingkan dengan model pembelajaran konvensional. Berdasarkan hasil pengujian hipotesis di atas, dapat disimpulkan bahwa penggunaan model Kolb efektif dalam meningkatkan hasil belajar siswa kelas XI. di MA. Mu'allimin NW Pancor.

Kata Kunci: Efektivitas, Model Kolb, Hasil Belajar

\section{PENDAHULUAN}

Masalah pendidikan sama sekali tidak bisa dipisahkan dari kehidupan manusia. Pendidikan bagi kehidupan manusia merupakan kehidupan mutlak yang harus dipenuhi sepanjang hayat. Tanpa pendidikan suatu kelompok manusia akan sulit untuk hidup berkembang sejalan dengan cita-citanya untuk maju. Sejauh ini masalah pendidikan kita masih di dominasi oleh pandangan bahwa pengetahuan sebagai perangkat fakta-fakta yang harus di hafal, kelas masih berfokus pada guru sebagai sumber utama pengetahuan kemudian ceramah sebagai sumber utama strategi belajar yang dominan. Hal ini berdampak negatif bagi siswa, mereka menganggap pembelajaran IPS khususnya pelajaran ekonomi sebagai pembelajaran yang membosankan, belajar yang penuh hapalan sehingga mengakibatkan kurangnya motivasi siswa dalam mengikuti proses belajar mengajar ekonomi dan secara langsung mempengaruhi hasil belajar siswa.

Mengatasi masalah tersebut di atas, sebagai guru maka sewajarnya ikut berpartispasi mengambil peranan dalam memikirkan usaha peningkatan strategi dan teknik-teknik pengajaran yang tepat dan cocok sesuai dengan perkembangan pendidikan pada saat ini. Guru senantiasa berupaya agar siswa mencapai keberhasilan belajar sesuai dengan kompetensi yang telah ditetapkan, keberhasilan proses belajar dikatakan optimal apabila hasil yang diperoleh sesuai dengan harapan. ${ }^{1}$

Hasil observasi partisipatif proses pembelajaran pada siswa kelas XI MA Mu'allimin NW Pancor pada kenyataanya, suasana belajar yang efektif belum

\footnotetext{
${ }^{1}$ Hamzah. Model-model pengukuran hasil belajar. (Penerbit : USU Press, Tahun 2012), hal. 11.
} 
sepenuhnya dapat diciptakan, khususnya dalam proses pembelajaran ekonomi. Guru masih menggunakan metode konvensional dalam penyampaian materi, kegiatan guru di kelas masih mengguakan metode ceramah, diskusi dan tanya jawab. Metode yang diterapkam berkesan monoton dan tidak bervariasi. Hal ini menyebabkan siswa berkesan hanya fokus pada guru sehingga membuat siswa menjadi pasif, hanya menerima dan menyimpan data, fakta dan teori saja, tetapi tidak berkesempatan untuk mengolah hingga memiliki kemampuan berfikir yang tajam. ${ }^{2}$

Model/pendekatan pembelajaran yang di terapkan oleh guru untuk membantu proses berpikir siswa, salah satunya adalah pembelajaran yang bersifat kontruktivisme. Pembelajaran Kontruktivisme merupakan pembelajaran yang menekankan pada pentingnya siswa membangun sendiri pengetahuan mereka lewat keterlibatan aktif proses belajar mengajar. Model Kolb merupakan salah satu pembelajaran yang bersifat Kontruktivisme, karena sama-sama menekanakan siswa membangun sendiri pengetahuannya yang meliputi: (1) penglaman baru (feeling), (2) refletion (observation), (3) abstract concep (creating), (4) menerapakan (active experimentation). ${ }^{3}$

Pembelajaran model Kolb akan dapat merangsang siswa berfikir lebih tinggi (mandiri) dalam situasi berorientasi masalah termasuk didalamnya belajar. Pembelajaran Kolb lebih memberikan kesempatan pada siswa untuk dapat mengembangkan observasi dalam menyelesaikan masalah-maslah kehhidupan sehari-hari. Teknik ini disamping memancing sifat keperibadian yang mandiri, juga dapat meningkatkan minat belajar. Berdasarkan informasi yang diperoleh melalui observasi yang dilaksanakan dengan mewawancarai guru IPS di MA Mu'allimin NW Pancor diperoleh data nilai semester II untuk kelas XI, berdasarkan nilai tersebut dapat di hitung nilai rata-rata kelas dan ketuntasan secara klasikal.

Berdasarkan data yang kami ketahui bahwa hasil belajar siswa rendah dimana masih terdapat $50 \%$ siswa yang dapat mencapai nilai KKM dari standar yang telah ditentukan. Hal ini disebabkan oleh beberapa faktor antara lain, aktivitas siswa di dalam kelas hanya mendengar, mencatat apa yang diberikan guru, dan mengerjakan soal secara individu di tempat duduk masing-masing. Sebagian besar siswa juga malu dan tidak mau bertanya meskipun mereka belum memahami penjelasan guru, siswa kurang siap dalam

${ }^{2}$ Budiningsih, Asri. Belajar dan Pembelajaran. (Jakarta: PT Rineka Cipta, Tahun 2005), hal 15.

${ }^{3}$ Nasution, S. 2009. Model-model pembelajaran dan pendekatannya. (Jakarta : PT. Bumi Aksara, Tahun 2009). 
mengikuti pelajaran pada setiap pertemuan karena sebagian besar siswa tidak mempelajari materi yang akan dibahas sebelum proses belajar mengajar dimulai, sehingga partisipasi siswa untuk menemukan sendiri pemecahan masalah menjadi kurang.

Sehubungan dengan hal itu, peneliti bekerja sama dengan guru IPS kelas XI IPS MA Mu'allimin NW Pancor mencoba menerapkan suatu model pembelajaran yang akan mengaktifkan siswa dalam pembelajaran. Model pembelajaran tersebut diharapkan dapat menghidupkan interaksi antara siswa dengan guru, siswa dengan siswa, serta keterlibatan siswa dalam proses belajar mengajar sehingga dapat meningkatkan hasil belajar dalam pembelajaran IPS.

Salah satu model yang dapat mewujudkan hal tersebut adalah model pengajaran kolb. Untuk mendapatkan kesimpulan yang baik tentang pembelajaran ini peneliti sangat tertarik untuk melakukan penelitian yang berjudul "Efektivitas Model Pembelajaran Kolb Dalam Meningkatkan Hasil Belajar Siswa Kelas XI IPS MA Mu'allimin NW Pancor”.

\section{METODE PENELITIAN}

Jenis penelitian yang digunakan dalam penelitian ini adalah penelitian eksperimen. Dalam penelitian eksperimen ada perlakuan (treatment), penelitian eksperimen dapat diartikan sebagai metode penelitian yang digunakan untuk mencari pengaruh perlakuan tertentu terhadap yang lain dalam kondisi yang terkendalikan, metode ini sebagai bagian dari metode kuantitatif mempunyai ciri khas tersendiri terutama dengan adanya kelompok kontrol.

Terdapat beberapa bentuk desain eksperimen yang dapat digunakan dalam penelitian bisnis, yaitu: Pre-Experimental Design, dan Quasi Eksperimental Design. maka penelitian ini termasuk penelitian Quasi Eksperimental Design dengan jenis PretestPosttest Control Group Design. Dalam rancangan ini, kelompok eksperimen diberi perlakuan sedangkan kelompok kontrol tidak. Pada kedua kelompok diawali dengan pretes, dan setelah pemberian perlakuan diadakan pengukuran kembali (post-test). ${ }^{4}$

Dalam penelitian ini siswa dikenai perlakuan berupa Model Pembelajaran Kolb untuk kelompok eksperimen dan metode konvensional untuk kelompok kontrol. Agar

${ }^{4}$ Sugiyono. Metode Penelitian Kuantitatif, Kualitatif, dan R \& D. (Bandung : Penerbit Alfabeta, Tahun 2010), hal. $72-73$. 
penelitian ini dapat berjalan dengan lancar, efektif, dan efisien maka perlu adanya suatu metode penelitian sesuai dengan obyek yang diteliti.

Penelitian eksperimental menggunakan suatu percobaan yang dirancang secara khusus guna membangkitkan data yang diperlukan untuk menjawab pertanyaan penelitian. Penelitian yang menggunakan rancangan percobaan dianggap sebagai jenis penelitian yang paling diinginkan oleh seorang peneliti. Yang dimaksud dengan "percobaan" ialah bagian penelitian yang membandingkan dua kelompok sasaran penelitian. Satu kelompok diberi perlakuan khusus tertentu dan satu kelompok lagi dikendalikan pada suatu keadaan yang pengaruhnya dijadikan sebagai pembanding. Karena itu, kelompok kedua ini dinamakan kelompok kendali, kelompok kontrol atau kelompok pembanding. Selisih tanggap antara kelompok perlakuan dengan kelompok kontrol menjadi ukuran pengaruh perlakuan yang diberikan kepada kelompok perlakuan itu. $^{5}$

Populasi dalam penelitian ini adalah tiga kelas atau seluruh siswa kelas XI.IPS MA Mu'allimin NW Pancor dengan jumlahnya 88 siswa.

Populasi bukan hanya orang, tetapi juga obyek dan benda-benda alam yang lain. Polpulasi ini juga bukan sekedar jumlah yang ada pada obyek/subyek yang dipelajari, tetapi meliputi seluruh karakteristik/sifat yang dimiliki oleh subyek atau obyek itu. ${ }^{6}$

Sedangkan yang menjadi sampelnya diambil pada kelas XI IPS yang terdiri dari dua kelas yaitu kelas XI.1PS.I dan kelas XI.IPS 2, yang kemudian kelas XI.IPS.1 dijadikan sebagai kelas kontrol dan kelas XI.IPS 2 sebagai kelas eksperimen dan mendapatkan perlakuan dengan menggunakan Model Pembelajaran Kolb. Kelas XI IPS.I berjumlah 29 orang dan kelas XI IPS.2 berjumlah 29 orang.

Sampel adalah bagian dari jumlah dan karakteristik yang dimiliki oleh populasi tersebut. Bila populasi besar dan peneliti tidak mungkin mempelajari semua yang ada pada populasi. Sampel yang diambil dari populasi harus betul-betul representative (mewakili). ${ }^{7}$

Teknik pengumpulan data yang digunakan adalah teknik tes dan wawancara. Instrument yang digunakan dalam penelitian ini berupa Rencana Pelaksanaan

\footnotetext{
${ }^{5}$ Margono. Metodologi Penelitian Pendidikan. Jakarta : PT. Rineka Cipta. Tahun 2005), hal. 39.

${ }^{6}$ Ibid, hal. 80.

${ }^{7}$ Ibid, hal. 81 .
} 
Pembelajaran (RPP) dan tes prestasi. Tes prestasi berbentuk tes objektif sebanyak 30 soal. Pemilihan bentuk ini bertujuan untuk menghindari spikulasi siswa dalam menjawab soal. Instrument yang baik harus memenuhi dua persyaratan penting yaitu valid dan reliabel. Sedangkan teknik analisi data yang digunakan adalah uji normalitas dan uji homogenitas.

\section{HASIL PENELITIAN}

\section{A. Deskripsi Data Hasil Penelitian}

Dalam penelitian ini mengujicobakan sekaligus membandingkan dua model pembelajaran yaitu model pembelajaran Kolb dan model pembelajaran konvensional (ceramah). Masing-masing kelompok diberikan perlakuan yang berbeda, kemudian untuk mengukur hasil belajar siswa masing-masing kelompok baik kelompok eksperimen (model Kolb) maupun kelompok kontrol (model konvensional) diberikan pre test. Hasil belajar IPS Ekonomi menjadi tujuan dalam penelitian ini. Untuk mengetahui kemampuan tersebut, diberikan tes awal (pre-test) sebelum diterapkan pembelajaran model kolb dan post-test diberikan setelah pembelajaran model kolb diterapkan.

Tabel 1. Nilai Rata-Rata hasil belajar IPS Ekonomi

Pada Kelas Kontrol dan Kelas Eksperiment.

\begin{tabular}{|l|l|l|}
\hline \multicolumn{1}{|c|}{ Kelompok } & \multicolumn{2}{|c|}{ Nilai Rata-Rata } \\
\cline { 2 - 3 } & Pre-test & Pos-test \\
\hline Kelas Kontrol & 55,56 & 62,56 \\
\hline Kelas Eksperiment & 68,94 & 74,07 \\
\hline
\end{tabular}

Dari hasil analisis skor untuk kelas kontrol pada saat pre test di peroleh nilai ratarata 55,56 dan nilai rata-rata pos test kelas kontrol 62,56 Pada kelas eksperiment nilai rata-rata pre test 68,94 , dan nilai pos test 74,07 . Ini menunjukkan bahwa penerapan pembelajaran model kolb pada kelas eksperiment memberi perbedaan nilai hasil belajar pada siswa kelas XI MA Mu'allimin NW Pancor. setelah diterapkan model pembelajaran kolb di kelas eksperimen danpembelajaran konvensional pada kelas kontrol diberikan post test yang berbentuk tes hasil belajar. Adapun hasil dari pemberian post test untuk 
masing-masing kelompok dapat dilihat pada lampiran 12. dan dalam bentuk ringkas disajikan dalam Tabel dibawah ini:

Tabel 2. Data Hasil Post Test Kelompok Eksperimen dan Kelompok Kontrol

\begin{tabular}{|c|c|c|c|c|}
\hline Kelompok & $\begin{array}{c}\text { Jumlah } \\
\text { Siswa }\end{array}$ & $\begin{array}{c}\text { Total } \\
\text { Skor }\left(\sum \mathrm{X}\right)\end{array}$ & Mean $\overline{\mathrm{X}})$ & $\begin{array}{c}\text { Standar } \\
\text { Deviasi (SD) }\end{array}$ \\
\hline Eksperimen & 29 & 2148 & 74,07 & 13,78 \\
\hline Kontrol & 29 & 1800 & 62,56 & 8,97 \\
\hline
\end{tabular}

Dari tabel di atas, besarnya rata-rata hasil belajar $(\overline{\mathrm{X}})$ yang dicapai oleh siswa pada kelompok eksperimen adalah sebesar 74,07 dengan total skor keseluruhan siswa $\left(\sum \mathrm{X}\right)$ pada kelompok ini adalah 2148. Dan memiliki nilai standar deviasi (SD) sebesar 13,78. Sedangkan pada kelas kontrol memiliki rata-rata prestasi sebesar 62,94 dengan total skor keseluruhan siswa $\left(\sum X\right)$ pada kelompok ini adalah 1800. Dan memiliki nilai standar deviasi (SD) sebesar 8,97.

Tabel 3. Distribusi Frekuensi Data Hasil Ppre Test Siswa yang Diajar dengan Menggunakan Model Pembelajaran konvensional (ceramah)

\begin{tabular}{|c|c|c|c|}
\hline No. & Kelas Interval & Titik Tengah & Frekuensi \\
\hline 1 & $47-53$ & 50 & 3 \\
\hline 2 & $54-60$ & 57 & 6 \\
\hline 3 & $61-67$ & 64 & 5 \\
\hline 4 & $68-74$ & 71 & 7 \\
\hline 5 & $75-81$ & 78 & 4 \\
\hline 6 & $82-89$ & 85 & 4 \\
\hline & $\sum$ & 405 & 29 \\
\hline
\end{tabular}


Tabel 4. Distribusi Frekuensi Data Hasil Post Test Siswa Yang Diajar Dengan Menggunakan Model Kolb

\begin{tabular}{|c|c|c|c|}
\hline No. & Kelas Skor & $\begin{array}{c}\text { Titik } \\
\text { Tengah }\end{array}$ & Frekuensi \\
\hline 1 & $45-52$ & 48,5 & 3 \\
\hline 2 & $53-60$ & 56,5 & 6 \\
\hline 3 & $61-68$ & 64,5 & 5 \\
\hline 4 & $69-76$ & 72,5 & 7 \\
\hline 5 & $77-84$ & 80,5 & 4 \\
\hline 6 & $85-92$ & 88,5 & 4 \\
\hline & $\sum$ & - & 29 \\
\hline
\end{tabular}

Dari tabel diatas terdapat perbedaan antara distribusi frekuensi data hasil pre tes dan post tes dilihat dari nilai titik tengah hasil post test lebih tinggi dari pre test karena sudah diterapkan model pembelajaran kolb.

\section{B. Uji Normalitas Data}

Pengujian normalitas data dimaksudkan untuk mengetahui keadaan data yang akan diolah sudah berdistribusi normal atau tidak. Pengujian dilakukan dengan menggunakan metode Chi Kuadrat $\left(\chi^{2}\right)$. Data yang diuji diambil dari hasil post-test masing-masing kelompok seperti yang terdapat pada lampiran 14, dari data tersebut dilakukan perhitungan sesuai dengan rumus yang digunakan. Hasil dari perhitungan uji normalitas ini disajikan secara ringkas pada tabel di bawah.

Tabel 5. Ringkasan Uji Normalitas Data Hasil Pre Test

\begin{tabular}{|c|c|c|c|}
\hline Kelompok & $\mathrm{X}^{2}$ hitung & $\mathrm{X}^{2}$ tabel & Kriteria \\
\hline Eksperimen & 1,407 & 11,070 & Terdistribusi normal \\
\hline Kontrol & 6,2 & 11,070 & Terdistribusi normal \\
\hline
\end{tabular}

Dari tabel di atas dapat dilihat bahwa nilai X2 hitung untuk masingmasing kelompok lebih kecil dari nilai X2 tabel pada taraf signifikan 5\% dan dk $=6$, sehingga dapat disimpulkan bahwa kedua kelompok berasal dari sampel yang berdistribusi normal. 
Tabel 6. Ringkasan Uji Normalitas Data Hasil Post-Test

\begin{tabular}{|c|c|c|c|}
\hline Kelompok & $\chi^{2}$ hitung & $\chi^{2}$ tabel & Kriteria \\
\hline Eksperimen & 9,8347 & 11,070 & Terdistribusi normal \\
\hline Kontrol & 7,79 & 11,070 & Terdistribusi normal \\
\hline
\end{tabular}

Dari tabel di atas dapat dilihat bahwa nilai $\chi^{2}$ hitung untuk masingmasing kelompok lebih kecil dari nilai $\chi^{2}$ tabel pada taraf nyata 5\%, sehingga dapat disimpulkan bahwa kedua kelompok berasal dari sampel yang terdistribusi normal.

\section{Uji Homogenitas Data}

Untuk menguji homogenitas data dalam penelitian ini digunakan rumus uji kesamaan dua varians. Adapun pengujian ini dimaksudkan untuk mengetahui homogen atau tidaknya data hasil pre test kelompok siswa yang diajar dengan model pembelajaran kelompok yang diajarkan dengan model pembelajaran Konvensional. Diperoleh Fhitung lebih kecil dari Ftabel yaitu Fhitung $=2,26<$ Ftabel $=2,92$ sehingga sampel-sampel dalam data ini dapat disimpulkan berasal dari populasi yang homogen.

Untuk menguji homogenitas data dalam penelitian ini digunakan rumus uji kesamaan dua varians. Adapun pengujian ini dimaksudkan untuk mengetahui homogen atau tidaknya data hasil post test kelompok siswa yang diajar dengan model Kolb serta kelompok yang diajarkan dengan model konvensional (ceramah). Diperoleh Fhitung lebih besar dari Ftabel yaitu Fhitung $=(2,042)>$ Ftabel $=(1,96)$ sehingga sampelsampel dalam data ini dapat disimpulkan berasal dari populasi yang homogen.

\section{Uji Hipotesis}

Setelah terpenuhinya persyaratan analisis (uji normalitas dan homogenitas), maka dapat dilakukan uji hipotesis dengan menggunakan rumus uji t 2 pihak seperti yang tecantum. Berdasarkan hasil perhitungan (lampiran 16 ), diperoleh harga thitung $=13,18$ dan ttabel $=2,0042$ pada taraf signifikasi $5 \%$ dengan $\mathrm{dk}=56$. Karena thitung $>$ ttabel $(13,18>2,0042)$ maka H0 ditolak dan Ha diterima yang berarti bahwa pembelajaran dengan menggunakan model Kolb lebih efektif dibandingkan dengan model pembelajaran konvensional (ceramah). 


\section{PEMBAHASAN HASIL PENELITIAN}

Model Kolb merupakan salah satu model pembelajaran inovatif yang terimplisit dalam resource besed learning (belajar berdasarkan masalah) yang mengajak siswa melakukan observasi untuk memecahkan masalah sehingga dapat memberikan kondisi belajar aktif kepada siswa. Dalam hal ini siswa dituntut untuk terlibat aktif memecahkan suatu masalah melalui tahap-tahap metode ilmiah sehingga siswa dapat mempelajari pengetahuan yang berhubungan dengan masalah tersebut dan sekaligus memiliki ketrampilan untuk memecahkan masalah.

Kolb merupakan pembelajaran Kontruktivisme karena pada dasarnya sama-sama menekankan pada pentingnya siswa membangun sendiri pengetahuan mereka lewat keterlibatan aktif proses belajar mengajar. Proses belajar mengajar lebih diwarnai student centered daripada teacher centered. Sebagkian besar waktu proses belajar mengajar berlqangsung denganberbasis pada aktivitqs siswa. Ide-ide Kontruktivisme modern banyak berlandaskan pada teori Vygostsky yang telah digunakan untuk menunjang metode pengajaran yang menekankan pada pembelajaran kooperatif, pembelajaran berbasis kegiatan, dan penemuan. Ia mengemukakan bahwa siswa belajar melaluin intraksi dengan orang dewasa atau teman sebaya yang lebih mampu. ${ }^{8}$

Peserta didik tidak lagi diberikan materi belajar secara satu arah seperti pada metode pembelajaran konvensional. Pada model pembelajaran konvensional pebelajar dikondisikan untuk mendengarkan, menghafal dan belajar termasuk mengajukan pertanyaan, siswa menerima informasi secara pasif, siswa belajar secara individual, pembelajaran tidak memperhatikan pengalaman siswa, dan hasil belajar diukur hanya dengan tes.

Menghafalkan fakta dan informasi sebenarnya bukan cara untuk belajar tetapi ini biasa dilakukan dalam suatu kegiatan pembelajaran menggunakan model konvensional. Sehingga lebih penting mengetahui bagaimana cara memproses informasi dibanding hanya mengetahui fakta yang nyata. Berbeda dengan model konvensional, pada model Pembelajaran Kolb siswa dididik untuk dapat mengembangkan pengetahuan mereka secara mandiri. Model ini melibatkan pengalaman baru siswa, mengembangkan

\footnotetext{
${ }^{8}$ Trianto. Mendesain Model Pembelajaran Inovatif-Progresif. (Jakarta : PT Kencana. Tahun 2009), hal. 6.
} 
observasi/ merefleksi, menciptakan konsep, dan menggunakan teori untuk memecahkan masalah.

Dalam penelitian ini peneliti mengambil pokok bahasan "Sistem imformasi akuntansi” dalam menerapkan Model Pembelajaran Kolb. Sedangkan langkah yang digunakan peneliti yakni, peneliti menugaskan siswa untuk memecahkan permasalahan yang di ajukan peneliti "berdasarkan pengalaman dan teori-teori yang kalian ketahui susunlah sistem informasi akuntansi dari teransaksi-teransaksi berikut. Kemudian peneliti menugaskan untuk mencari konsep-konsep sistem informasi akuntansi yang mereka lakukan. Setelah itu peneliti berdiskusi dengan siswa untuk memecahkan masalah yang muncul dari perolehan siswa tentang konsep-konsep sistem informasi akuntansi. Kemudian peneliti menugaskan siswa mengimplikasikan penemuannya dengan teori yang ada, dalam hal ini pada pokok bahasan sistem impormasi akuntansi . Setelah teori dengan penemuan siswa yang diperoleh dari pengalaman mereka mengukur dan memperoleh konsep-konsep sesuai dengan teori yang ada, peneliti menugaskan siswa untuk menjadikan teori dan pengalaman yang mereka peroleh dari pokok bahasan sistem impormasi akuntansi sebagai pegangan untuk memecahkan masalah yang ada selanjutnya. Pada saat diberikan pre test nilai hasil belajar siswa masih rendah, akan tetapi setelah di terapkan model pembelajaran Kolb dan setelah mempelajari materi siswa di berikan post test hasil belajar siswa lebih meningkat. Oleh karna itu model pembelajaran Kolb dapat meningkatkan hasil belajar siswa.

Siswa yang berhasil dalam belajar adalah yang berhasil mencapai tujuan-tujuan pembelajaran atau tujuan instruksional. Menurut Benjamin S. Bloom tiga ranah (domain) hasil belajar, yaitu kognitif, afektif, dan psikomotorik. Dapat kita simpulkan bahwa hasil belajar pencapaian bentuk perubahan perilaku yang cenderung menetap dari ranah kognitif, afektif dan psikomotoris dari proses belajar yang dilakukan dalam waktu tertentu. ${ }^{9}$

Dari hasil penelitian menunjukkan bahwa terdapat perbedaan hasil belajar antara siswa yang diajar dengan menggunakan model pembelajaran Kolb dibandingkan dengan siswa yang diajar dengan model pembelajaran konvensional. Siswa yang diajar dengan menggunakan model Kolb memiliki rata-rata skor yang lebih tinggi dibandingkan dengan

${ }_{9}^{9}$ Jihad, Asep dan Haris,Abdul. Evaluasi Pembelajaran. (Jakarta : Multi Pressindo. Tahun 2008), hal. 14. 
siswa yang diajar dengan model konvensional. Ini disebabkan karena model Kolb membuat siswa untuk selalu aktif dalam setiap segi pembelajaran, dalam hal ini siswa dituntut untuk menghadapi dan memecahkan masalah secara mandiri melalui tahap pengalaman konkrit dimana pada tahap ini seorang siswa hanya mampu ikut mengalami suatu kejadian, dari sinilah terjadi tahap awal proses pembelajaran. Selanjutnya pengalaman aktif dan reflektif dimana siswa lambat laun melakukan pengamatan aktif terhadap kejadian itu, dan mulai berusaha memikirkan serta memahaminya. Selain itu melalui tahap konseptualisasi dimana siswa mulai belajar membuat abstrak atau teori tentang hal yang pernah diamatinya. Terakhir, eksperimentasi aktif dimana siswa sudah mampu mengaplikasikan suatu autran umum ke situasi yang baru. Sehingga dalam hal ini, pengalaman belajar benarbenar didapatkan oleh siswa. Dengan demikian, dalam model Kolb masalah yang muncul digunakan sebagai sarana agar siswa dapat belajar sesuatu yang dapat menyokong keilmuannya.

Namun demikian, tidak selamanya proses kegiatan belajar mengajar dengan model Kolb berjalan dengan lancar. Ada beberapa hambatan yang dapat muncul. Yang sering terjadi adalah kurang terbiasanya peserta didik dan pengajar dengan model pembelajaran ini. Apalagi jika terdapat peserta didik yang tidak mau memahami potensi dirinya tentunya akan menyebabkan ketinggalan dalam proses belajar, peserta didik yang tidak aktif dan malas belajar akan merugikan diri sendiri dalam proses belajar. Masalah ini disebabkan karena peserta didik dan pengajar masih terbawa kebiasaan model konvensional, pemberian materi terjadi secara satu arah. Faktor penghambat lain adalah kurangnya waktu. Proses model pembelajaran Kolb terkadang membutuhkan waktu yang lebih banyak. Peserta didik terkadang memerlukan waktu untuk menghadapi permasalahan yang diberikan. Sementara, waktu pelaksanaan model Kolb harus disesuaikan dengan waktu yang sudah disediakan dalam kurikulum.

Hasil pengujian secara statistik terhadap hasil post test masing-masing kelompok dengan menggunakan uji-t, menunjukkan hasil bahwa kelompok siswa yang diajar dengan menggunakan model Kolb dengan kelompok siswa yang diajarkan dengan model konvensional berbeda pada taraf signifikasi 5\%. Adapun hasil menggunakan model Kolb lebih efektif dibandingkan dengan model konvensional.

Walaupun demikian, efektif tidaknya suatu kegiatan pembelajaran yang dalam hal ini kegiatan pembelajaran dengan menggunakan model Kolb dan konvensional, itu tidak 
terlepas dari beberapa faktor yang mepengaruhi tingkat keberhasilan suatu kegiatan pembelajaran. Salah satu faktor yang mempengaruhi hasili belajar adalah lingkungan. Semakin baik lingkungan belajar semakin baik pula hasil belajar yang dapat dicapai oleh siswa, begitu pula sebaliknya lingkungan belajar yang kurang baik akan berpengaruh juga pada kurang baiknya hasil belajar siswa. Hal itu berlaku juga bagi hasil belajar (IPS) Ekonomi.

Dalam Model Pembelajaran Kolb hakekatnya belajar dengan menyenangkan. Karena model pembelajaran ini mengutamakan masalah yang diperoleh siswa sendiri sehingga siswa lebih mudah mencerna dan memahami konsep yang diberikan. Demikian pula dalam belajar (IPS) Ekonomi yang harus dilakukan terlebih dahulu memberikan motivasi yang sesuai karena keberhasilan belajar dan motivasi sangat berpengaruh dalam menentukan Hasil belajar (IPS) Ekonomi siswa.

Sedangkan dalam pembelajaran konvensional, belajar hanya bertumpu pada pengajar sebagai pusat informasi, sehingga membuat siswa cepat merasa bosan dan terlebih lagi mereka akan merasa (IPS) Ekonomi itu tidak menyenangkan, padahal telah dipaparkan sebelumnya bahwa belajar didasari kesenangan maka akan diperoleh hasil yang baik. Maka dari itu seorang guru harus mempunyai keterampilan untuk memotivasi siswa terutama dalam belajar (IPS) Ekonomi.

Dari penjelasan tersebut dapat dilihat dengan jelas bahwa Model Pembelajaran Kolb mempunyai pengaruh yang lebih baik terhadap hasil belajar (IPS) Ekonomi dibandingkan dengan pembelajaran Konvensional. Karena dalam Model Pembelajaran Kolb terdapat kreatifitas guru yang berbeda dengan cara belajar Konvensional dalam memotivasi siswa yang selanjutnya akan berdampak pada hasil belajar (IPS) Ekonomi siswa. Dan model pembelajaran kolb banyak membawa dampak positif baik bagi guru maupun bagi siswa di lihat dari penelitian terdahulu yang dilakukan oleh Suryani (2009) 99,9\% mengalami ketuntasan belajar siswa. Selain itu juga dilihat dari masing-masing kelompok, sudah terlihat adanya komunikasi dan intraksi yang baik antar kelompok, dilihat dari hasil penelitian maka model pembelajaran Kolb sangat berpengaruh terhadap siswa dengan danya penelitian yang terdahulu dapat kita kaitkan bahwa model Kolb dapat meningkatkan hasil belajar siswa. 


\section{KESIMPULAN}

Berdasarkan hasil penelitian dan analisa data yang sudah dilakukan, serta mengacu pada tujuan dari penelitian ini, maka dapat disimpulkan bahwa dari hasil pengujian secara statistik terhadap hasil post test masing-masing kelompok dengan menggunakan uji-t, menunjukkan hasil bahwa kelompok siswa yang diajar dengan menggunakan model Kolb dengan kelompok siswa yang diajarkan dengan model konvensional berbeda pada taraf signifikasi 5\%.

Adapun hasil perhitungan yang diperoleh yaitu thitung $=13,18$ nilai ini lebih tinggi dibandingkan dengan harga ttabel yaitu 2,0042 dengan kata lain hipotesis Ho ditolak dan Ha diterima. Selain itu juga siswa yang diajar dengan menggunakan model Kolb memiliki rata-rata hasil belajar yang lebih tinggi dibandingkan dengan siswa yang diajar dengan model konvensional, yakni 74,07 pada kelas Kolb dan 62,56 pada kelas konvensional. Dengan demikian dapat disimpulkan bahwa pembelajaran dengan menggunakan model pembelajaran Kolb efektif dalam meningkatkan hasil belajar siswa MA Mu'allimin NW Pancor.

\section{SARAN}

Ada beberapa saran yang dapat penulis berkaitan dengan hasil penelitian ini antara lain:

1. Bagi siswa agar terbiasa menerapkan model pembelajaran kolb untuk memberi peluang kepada peserta didik untuk mengungkapkan gagasan berdasarkan hasil intraksi dengan lingkungan, yang bertujuan akan membuat mata pelajaran lebih dipahami dan menarik.

2. Pada dasarnya untuk kegiatan pembelajaran dapat digunakan berbagai model mengacu pada materi pengajaran yang akan disampaikan. Dalam kaitannya dengan pembelajaran ekonomi pokok bahasan sistem imformasi akuntansi di tingkat SMA/MA dapat digunakan model pembelajaran Kolb karena terbukti mampu meningkatkan hasil belajar siswa. Oleh karena itu guru hendaknya mempertimbangkan penggunaan metode ini saat akan melaksanakan pembelajaran.

3. Dalam pelaksanaan pembelajaran Kolb agar mencapai hasil yang optimal, guru perlu melakukan penataan ruang secara efektif untuk menghindari suasana gaduh saat pembentukan kelompok. 
4. Kepada peneliti lain dapat melakukan penelitian serupa pada pokok bahasan lain, sehingga diperoleh informasi lebih luas tentang keefektifan pembelajaran model Kolb dalam pembelajaran ekonomi pada siswa.

\section{DAFTAR PUSTAKA}

Budiningsih, Asri. (2005). Belajar dan Pembelajaran. Jakarta: PT Rineka Cipta. Hamzah. (2012). Model-model pengukuran hasil belajar. Penerbit : USU Press. Jihad, Asep dan Haris,Abdul. (2008). Evaluasi Pembelajaran. Jakarta : Multi Pressindo. Margono. (2005). Metodologi Penelitian Pendidikan. Jakarta : PT. Rineka Cipta.

Nasution, S. (2009). Model-model pembelajaran dan pendekatannya. Jakarta : PT. Bumi Aksara.

Sugiyono. (2010). Metode Penelitian Kuantitatif, Kualitatif, dan R \& D. Bandung : Penerbit Alfabeta.

Trianto. (2009). Mendesain Model Pembelajaran Inovatif-Progresif. Jakarta : PT Kencana. 